\title{
Influence of sociodemographic factors on quality of life in women living in Lublin Province in Poland
}

\author{
Dorota Żołnierczuk-Kieliszek, Teresa B. Kulik, Mariola Janiszewska, Agata Stefanowicz
}

Katedra Zdrowia Publicznego Uniwersytetu Medycznego w Lublinie

\begin{abstract}
Aim of the study is to evaluate the impact of sociodemographic factors on the quality of life (QOL) in 45-65-year-old women.

Material and methods: The research by means of a survey method, postal questionnaire technique, comprised 2143 women - a representative sample of the female population living in Lublin Province. Three standardized questionnaires - WHOQOL-BREF, Women's Health Questionnaire and SF-36 - as well as an original questionnaire were used as research tools. In statistical analysis Student's $t$-test for two groups, an analysis of variance, Dunnett's T3 test for multiple comparisons, a one-way analysis of variance (one-way ANOVA) and a stepwise logistic regression analysis were used.

Results: In the population of peri- and postmenopausal women a significantly better quality of life in comparison with the rest of the studied women was established in women aged 45-49 years, respondents living permanently in urban areas as well as better educated women, those with full-time employment, especially those doing intellectual work, women remaining in a long-lasting relationship, and women assessing their financial situation and living conditions as well. Logistic regression analysis showed that the strong predictors of poor quality of life were as follows: self-assessment of living conditions as poor, self-assessment of financial situation as poor, permanent place of residence in the country, lower education level (incomplete primary education, primary education).

Conclusions: The group of women with worse quality of life should become the main addressee of preventive programmes and health policy programmes designed for peri- and postmenopausal women.
\end{abstract}

Key words: quality of life, women, menopause, WHQ, WHOQOL-BREF, SF-36.

\section{Introduction}

Recent studies point to the importance of the quality of life in people of different age groups.

In Poland the average women's age of the last period is 51 years [1]. The menopause transition causes many changes in women's life, not only biological changes, but also psychological and social ones. The changes are as follows: getting ill with somatic disease or aggravation of existing disease; having to deal with caring for and/or the death of elderly parents or an elderly spouse; empty nest syndrome when grown-up children leave home; and the change of socioeconomic status caused by retirement or receiving disability pension (their own or that of a spouse) [2, 3]. A positive correlation between low valuation of menopause profits or high valuation of menopause losses and high intensity of menopausal symptoms has been proved [4]. To estimate women's quality of life, we should pay attention to both physical and psychological and social state of women's health [5]. The quality of life in peri- and post- menopausal women constitutes a serious public health problem. This is due to current demographic trends in Polish society in which women in peri- and postmenopausal stages constitute an increasing proportion.

According to the Central Statistical Office the number of Polish women aged 45-64 years is almost 5.4 million [6].

The purpose of this research was to determine the impact of various sociodemographic factors on quality of life in peri- and postmenopausal women. The factors were as follows: women's age, permanent place of living, education, employment, marital status, having children, self-assessment of their financial situation and living conditions.

\section{Material and methods}

The research was carried out by means of a survey method, postal questionnaire technique. We used three standard questionnaires: Women's Health Ques- 
tionnaire (WHQ), WHOQOL-BREF and SF-36. An original questionnaire was also used. The questions included in the original questionnaire concerned women's sociodemographic data.

The research was conducted between April 2007 and October 2008. The postal questionnaires were sent to 7875 women aged 45-65, living in Lublin Voivodeship. The mail addresses of the representative sample of females aged 45-65 years living in Lublin Voivodeship were obtained from the Local Data Bank of Lublin Provincial Office. The Local Data Bank contains information about the gender, age, and address of every individual living in Lublin Voivodeship. We received 2,143 return letters with correctly filled questionnaires (return rate of $27.2 \%$ ). The structure of the sample according to age and permanent place of living did not differ from the structure of the general population, which means that the sample was representative for the population. We described women living permanently in towns and cities as urban dwellers and women living permanently in the country as rural dwellers or rural women.

The study results obtained were subjected to a statistical analysis. The domains of quality of life established by the WHQ, WHOQOL-BREF, and SF-36 questionnaires were treated as dependent variables, whereas the socio-demographic variables were treated as independent variables. Correlates of QOL were first investigated with a series of univariate analyses. Correlations between quantitative variables were estimated using Pearson's linear correlation coefficient. The analysis of qualitative variables was performed using Student's $t$-test for two groups and the analysis of variance when more than two groups were compared. For multiple comparisons, Dunnett's T3 test was used. The comparison of two means using Student's $t$-test was preceded by Levene's test for homogeneity of variances. When the variances in both groups differed significantly, a modified test for heterogeneous variances was used. For comparison of more than two means from independent groups, a oneway analysis of variance (one-way ANOVA) was used and was preceded by Levene's test for homogeneity of variances. The study also included two strong tests for equality of means - Welch's test and Brown-Forsythe's test. The adopted significance level of $p<0.05$ displayed statistically significant correlations. The second stage of statistic analysis involved a stepwise logistic regression analysis used to eliminate the possible disturbing influence of various independent variables. The values of dependent variables were dichotomized according to the median value. For each of the nine scales of WHQ, women showing values over the median value (i.e. worse QOL) were compared with the remainder. Similarly, for each of the four scales of WHO-BREF and each of the eight scales of SF-36, women showing values under the median value (i.e. worse $\mathrm{QOL}$ ) were compared with the remainder. The results of the logistic regres- sion analyses were expressed in terms of the odds ratio $(\mathrm{OR})$, together with its associated $p$ value.

\section{Results}

The analysis of the data obtained proved that the quality of life of younger women (45-49 years of age) was significantly better as compared with those aged 50-65. Younger women were marked by a better quality of life in most WHQ domains except for the menstrual symptoms domain, in which older women were characterized by a better quality of life, and except for depressed mood and anxiety/fears domains, where no statistically significant differences were found according to age. A better quality of life was revealed in younger women in all SF-36 subscales except for the mental health subscale as well as in all WHO-BREF domains except for the social relationships domain.

The respondents' quality of life was largely determined by the condition of being a rural or an urban dweller. The lowest quality of life was found in rural dwellers, while city and town inhabitants enjoyed a significantly better quality of life. Statistically significant correlations were found in all quality of life domains of the standard questionnaires, except for menstrual symptoms of WHQ $(p<0.05)$.

Women's quality of life was also significantly influenced by their level of education. The highest quality of life was observed in women with a bachelor's and master's degree and the lowest in those with unfinished primary, primary and gymnasium education. Statistically significant differences were revealed in all quality of life domains of the standard questionnaires, except for menstrual symptoms of WHQ $(p<0.05)$.

The respondents' quality of life was determined to a large extent by their professional status. Women in full-time employment enjoyed a significantly better quality of life than the other respondents in all WHOQOL-BREF domains and eight of nine SF-36 domains $(p<0.05)$. Menstrual symptoms was the only WHQ domain in which women in full-time employment were marked by a worse quality of life than the others. This means employed women suffered more from menstrual disorders and breast tenderness.

On the other hand, women who were paid disability pension or a family pension revealed a considerably lower level of quality of life than other respondents. A statistically significant dependence was established in all 21 domains of quality of life of standardized questionnaires used in the research $(p<0.05)$.

Quality of life was also largely determined by the practised full time profession. Statistically significant differences were observed in all quality of life domains of standard questionnaires used in the research ( $p<0.05$ ), except for the menstrual symptoms WHQ domain. A poorer quality of life was observed in female 
farmers and manual workers. A considerably higher quality of life was enjoyed by women who worked as teachers or performed other types of intellectual work or high-responsibility intellectual work $(p<0.05)$.

A significantly lower quality of life was observed in single women (unmarried women, women in separation, divorced or widowed) as compared with those in relationships (married or in informal relationships). Single women were characterized by significantly worse quality of life in depressed mood and attractiveness of WHQ, in all four WHOQOL-BREF domains and in three SF-36 subscales (general health, social functioning and mental health) $(p<0.05)$.

A slightly better quality of life was observed in childless women (as opposed to those with one or more children).

Women's quality of life was also considerably influenced by their financial situation. The more satisfied they were with their financial standing, the better the quality of their lives. Statistically highly significant correlations were found in all WHOQOL-BREF domains, all SF-36 subscales, as well as in eight of nine WHQ domains (except the domain menstrual symptoms of WHQ) $(p<0.001)$.

The study also revealed a statistically strong correlation between women's self-assessment of their living conditions and their quality of life. Good housing conditions corresponded to the highest quality of life,

Table I. Results of regression analysis - psychological domain of WHOQOL-BREF as dependent variable

\begin{tabular}{|c|c|c|c|}
\hline \multicolumn{2}{|c|}{ Independent variables } & \multirow{2}{*}{$\frac{\text { Odds ratio }}{1.00}$} & \multirow[t]{2}{*}{$p$} \\
\hline \multirow{4}{*}{ Age } & $45-49$ & & \\
\hline & $50-54$ & 0.80 & 0.138 \\
\hline & $55-59$ & 0.65 & 0.765 \\
\hline & $60-64$ & 0.62 & 0.024 \\
\hline \multirow{8}{*}{$\begin{array}{l}\text { Full-time } \\
\text { employment }\end{array}$} & unemployed & 1.35 & 0.003 \\
\hline & $\begin{array}{l}\text { profession not } \\
\text { specified }\end{array}$ & 1.20 & 0.562 \\
\hline & farmer & 0.77 & 0.029 \\
\hline & manual work & 1.62 & 0.420 \\
\hline & business activity & 2.52 & 0.128 \\
\hline & intellectual work & 0.89 & 0.010 \\
\hline & teacher & 0.65 & 0.005 \\
\hline & $\begin{array}{l}\text { responsible } \\
\text { intellectual work }\end{array}$ & 1.00 & \\
\hline \multirow{3}{*}{$\begin{array}{l}\text { Self-assessment } \\
\text { of financial } \\
\text { situation }\end{array}$} & good & 1.00 & \\
\hline & average & 0.71 & 0.016 \\
\hline & poor & 2.38 & $<0.0005$ \\
\hline \multirow{3}{*}{$\begin{array}{l}\text { Self-assessment } \\
\text { of housing } \\
\text { conditions }\end{array}$} & good & 1.00 & \\
\hline & average & 1.96 & 0.017 \\
\hline & poor & 2.77 & $<0.0005$ \\
\hline
\end{tabular}

average to mediocre quality of life, and poor living conditions were a determinant of the lowest quality of life. Statistically highly significant correlations were found in all WHOQOL-BREF domains, in all SF-36 subscales as well as in all WHQ domains $(p<0.001)$.

Since many of the variables investigated were correlated (i.e. age, school education, place of permanent residence, professional status, self-assessment of financial situation and living conditions), we applied a series of multiple logistic regression analyses to evaluate their independent role in predicting QOL. Its results were expressed as the odds ratio (OR).

Table I shows selected results of regression analysis for the psychological domain of WHOQOL-BREF, treated as dependent variable.

Table II presents selected results of regression analysis for general health subscale of SF-36, treated as a dependent variable.

Analogically to the selected domains of WHOQOLBREF and SF-36, a regression analysis was conducted for the remaining 19 quality of life domains of the standard questionnaires, treating them as dependent variables.

The analysis revealed the following predictors of a poorer quality of life:

- low self-assessment of living conditions and low selfassessment of financial situation, both increasing the risk of a poorer quality of life in ten quality of life domains,

- permanent place of residence in the country, increasing the risk of a worse quality of life in nine quality of life domains,

- unfinished primary, primary or gymnasium education, increasing the risk of a poorer quality of life in eight quality of life domains.

Table II. Results of regression analysis - general health subscale of SF-36 as dependent variable

\begin{tabular}{|c|c|c|c|}
\hline \multicolumn{2}{|c|}{ Independent variables } & \multirow{2}{*}{$\begin{array}{c}\text { Odds ratio } \\
1.00 \\
\end{array}$} & \multirow[t]{2}{*}{$p$} \\
\hline \multirow{4}{*}{ Age } & $45-49$ & & \\
\hline & $50-54$ & 0.73 & 0.307 \\
\hline & $55-59$ & 0.57 & 0.707 \\
\hline & $60-64$ & 0.61 & 0.007 \\
\hline \multirow{5}{*}{ Education } & $\begin{array}{l}\text { gymnasium and } \\
\text { lower }\end{array}$ & 2.00 & 0.02 \\
\hline & $\begin{array}{l}\text { vocational } \\
\text { secondary }\end{array}$ & 1.33 & 0.130 \\
\hline & secondary & 1.30 & 0.101 \\
\hline & bachelor's degree & 0.88 & 0.676 \\
\hline & $\begin{array}{l}\text { master's degree or } \\
\text { doctorate }\end{array}$ & 1.00 & \\
\hline \multirow{3}{*}{$\begin{array}{l}\text { Self-assessment } \\
\text { of housing } \\
\text { conditions }\end{array}$} & good & 1.00 & \\
\hline & average & 1.22 & 0.126 \\
\hline & poor & 1.96 & 0.057 \\
\hline
\end{tabular}




\section{Discussion}

The univariate analysis of our study results showed a significantly higher quality of life in younger women. Our results coincide in this respect with those obtained by Bińkowska [7], who in 2004 studied a representative group of 1083 Polish women aged 45-54. Other researchers [8-10] also confirm a negative impact of aging on the women's quality of life.

Our study showed that low education level was also a strong independent predictor of poorer quality of life. The univariate analysis revealed that women with a bachelor's or master's degree enjoyed a better quality of life than those with a low level of education. The existence of a negative correlation between women's level of education and their quality of life has been proved by other authors as well [11-15]. This correlation can be explained by the influence of intellectual potential in understanding of the aging process and the promoted healthy behaviours in better educated women [16].

Our data suggest that the respondents' quality of life was determined to a large extent by their professional status. Women who were full-time employees demonstrated a significantly better quality of life than the other respondents in all WHOQOL-BREF domains. The findings of Barnaś et al. confirmed the observation [17].

The univariate analysis of our study results also revealed that women's quality of life was significantly determined by their domicile. The worst quality of life was found in country dwellers, whereas city and town inhabitants enjoyed a significantly better quality of life. A similar correlation was observed by Bińkowska, who in 2004 conducted a large study on a representative sample of Polish women aged 45-54 [7]. The same was confirmed by Amore et al. [18], who studied the quality of life in Italian women, aged 45-65. In our study rural women showed considerably worse quality of life in depressed mood and anxiety domains of the WHQ questionnaire when compared to their city and town counterparts. Our results are similar to the conclusions reached by Malacara et al. [19], who comparing urban versus rural women aged 45-60 years in a multicentric, cross-sectional study from three different states of Mexico, estimated that scores for depression and anxiety were higher in rural women. Rural women of low socioeconomic status are more likely to encounter financial problems, issues of unemployment or underemployment, discrimination, lack of education, and single parenthood. Therefore, it is not unexpected that rural females possess higher risk of anxiety and depression problems [20].

Poorer quality of life outcomes in rural and remote areas are likely to be the result of factors such as greater socioeconomic disadvantage (lower levels of education and poorer access to work, particularly skilled work), poorer access to health services, higher levels of personal health risk factors, and environmental issues linked to road travel and occupation [18, 21]. Women living in the city have more opportunities to be involved in social, cultural or economic activities. In contrast, women in rural areas are more labile to a diminished self-esteem at the end of their child-bearing age.

In our study, we compared the quality of life in single women (unmarried, women in separation, divorced and widowed) with those in relationships (married or in informal relationships). The comparison revealed a significantly worse quality of life in single women. Similar conclusions were reached by Kaczmarek [16], who proved that the marital status of Polish women past surgical menopause was an important predictor of their psychological well-being. Women in informal relationships or married were in a much better physical and mental state than the single ones. Loneliness is an important risk factor of depression, other mental diseases and somatic diseases. The differential marital status effect on psychological well-being is usually explained by selective mating and protective role of marriage hypotheses. According to the first hypothesis, people of poor health are more often never married than their counterparts having good health [21]. The second hypothesis claims that marriage provides social, financial and emotional protection, which enables alleviation of menopausal suffering [22]. Similar conclusions were reached by Skrzypulec et al. [23].

Results of our own studies indicate that a slightly better quality of life was observed in childless women (as opposed to those with one or more children). These findings are inconsistent with a report by Gojdź et al. [24], who found a significantly better quality of life in Polish female physicians aged 45-55 years having children (as opposed to childless female physicians).

Our results showed that women more satisfied with their financial situation and housing conditions were marked by significantly better quality of life than other respondents. Low self-assessment of living conditions and low self-assessment of financial situation were also among strong predictors of a poorer quality of life in a logistic regression analysis. This corresponds to conclusions reached by Genazzani et al. [11], who evaluated the quality of life in Italian post-menopausal women.

\section{Conclusions}

1. In the population of peri- and postmenopausal women - inhabitants of Lublin Province - a significantly better quality of life in comparison with the rest of the studied women was established in women aged 45-49 years, respondents living permanently in urban areas as well as better educated women, those with full-time employment, especially those doing intellectual work, women remaining in a long-last- 
ing relationship, and women assessing their financial situation and living conditions as good.

2. Logistic regression analysis showed that the strong predictors of poor quality of life were as follows: self-assessment of living conditions as poor, self-assessment of financial situation as poor, permanent place of residence in the country, lower education level (incomplete primary education, primary education).

3. The group of women with worse quality of life should become the main addressee of preventive programmes and health policy programmes designed for peri- and postmenopausal women.

\section{Acknowledgements and funding}

The study was financed as a research project from science funds in 2007-2010. All participants gave their informed consent prior to their inclusion in the study.

\section{Disclosure}

Authors report no conflicts of interest.

\section{References}

1. Dąbrowska J, Naworska B, Dąbrowska-Galas M, et al. Rola wysitku fizycznego w okresie menopauzy. Prz Menopauz 2012, 16: 445-448.

2. Putyński L, Janicka K. Rola terapii hormonalnej w życiu kobiet w okresie menopauzy. Prz Menopauz 2011; 15: 457-463.

3. Jafary F, Afzali L. Porównanie skuteczności czterech modeli terapii grupowej w poprawie jakości życia kobiet w okresie menopauzalnym. Prz Menopauz 2013; 17: 194-201.

4. Bąk-Sosnowska M, Skrzypulec-Plinta V. Przyczyny nadmiernej masy ciata u kobiet w okresie menopauzalnym. Prz Menopauz 2012; 16: 31-35.

5. Piotrowska S, Majchrzycki M. Ćwiczenia fizyczne u kobiet po menopauzie. Prz Menopauz 2013; 17: 347-351.

6. Rocznik Demograficzny Głównego Urzędu Statystycznego. Zakład Wydawnictw Statystycznych, Warszawa 2009.

7. Bińkowska M. Badanie postaw i zachowań zdrowotnych oraz jakość życia reprezentatywnej grupy kobiet polskich w wieku od 45 do 54 lat. Prz Menopauz 2005; 9 supl. 1: 1-72.
8. Budakoglu I, Özcan C, Eroglu D, et al. Quality of life and postmenopausal symptoms among women in a rural district of the capital city of Turkey. Gynecol Endocrinol 2007; 23: 404-409.

9. Blumel JE, Castelo-Branco C, Binfa L, et al. Quality of life after the menopause: a population study. Maturitas 2000; 34: 17-23.

10. Chiu Y-W, Moore RW, Hsu CE, et al. Factors influencing women's quality of life in the later half of life. Climacteric 2008; 11: 201-211.

11. Genazzani AR, Nicolucci A, Campagnoli C, et al. Assessment of the QoL in Italian menopausal women: comparison between HRT users and non-users. Maturitas 2002; 42: 267-280.

12. Li C, Samsioe G, Borgfeldt C, et al. Menopause-related symptoms: what are background factors? A prospective population-based cohort study of Swedish women (The Women's Health in Lund Area study). Am J Obstet Gynecol 2003; 189: 1646-1653.

13. Lu J, Liu J, Eden J. The experience of menopausal symptoms by Arabic women in Sydney. Climacteric 2007; 10: 72-79.

14. Ozkan S, Alatas ES, Zencir M. Women's quality of life in the premenopausal and postmenopausal periods. Qual Life Res 2005; 14: 1795-1801.

15. Wiliams RE, Levine KB, Kalilani L, et al. Menopause-specific questionnaire assessment in US population-based study shows negative impact on health-related quality of life. Maturitas 2009; 62: 153-159.

16. Kaczmarek M. Reproductive health and psychological well-being of surgically menopausal Polish women. Acta Med Lituan 2008; 15: 43-48.

17. Barnaś E, Krupińska A, Kraśnianin E, et al. Funkcjonowanie psychospoteczne i zawodowe kobiet w okresie okołomenopauzalnym. Prz Menopauz 2012; 16: 296-304.

18. Amore M, Donato PD, Papalini A, et al. Psychological status at the menopausal transition: an Italian epidemiological study. Maturitas 2004; 48: 115-124.

19. Malacara JM, Cetina TC, Bassol S, et al. Symptoms at pre- and postmenopause in rural and urban women from three States of Mexico. Maturitas 2002; 43: 11-19.

20. Yee WS, Lin LP. Anxiety and depressive symptoms among communities in the east coast of Peninsular Malaysia: A rural exploration. MJP Online Early; available at: http://www.mjpsychiatry.org/index.php/mjp/article/ view/143 (access: 2013.10.20).

21. Marks NF, Lambert JD. Marital status continuity and change among young and midlife adults: longitudinal effects on psychological wellbeing. J Family Issues 1998; 19: 652-686.

22. Dennerstein L, Lehert P, Dudley E, et al. Factors contributing to positive mood during the menopausal transition. J Nerv Ment Disease 2001; 189: 84-49.

23. Skrzypulec W, Naworska B, Drosdzol A. Analiza wpływu objawów klimakterycznych na funkcjonowanie i jakość życia kobiet w okresie okotomenopauzalnym. Prz Menopauz 2007; 11: 96-101.

24. Gojdź K, Bąk-Sosnowska M, Kołodziej S, et al. Jakość życia polskich lekarek w wieku 45-55 lat. Prz Menopauz 2013; 17: 213-215. 